\title{
Annotated bibliography for Barrow Island terrestrial invertebrates
}

\author{
Christopher K. Taylor \\ Department of Environment and Agriculture, Curtin University, GPO Box U1987, Perth, Western \\ Australia 6845, Australia. Email: Chris.Taylor@curtin.edu.au
}

\begin{abstract}
A bibliography is provided of publications treating terrestrial invertebrates on Barrow Island. A brief overview is also given of natural history and invertebrate collections on Barrow Island.
\end{abstract}

KEYWORDS: Arthropoda, Insecta, Arachnida, Gastropoda, publication history

\section{INTRODUCTION}

As part of this special issue on the terrestrial invertebrate fauna of Barrow Island in Western Australia, we take the opportunity to present a bibliography of previous publications on the subject. A more general bibliography of Barrow Island's natural history was previously collated by Smith et al. (2006). The current bibliography differs from that in gathering not only publications for which Barrow Island was the primary focus, but also those in which Barrow Island specimens were considered as part of a broader study.

\section{HISTORY OF INVERTEBRATE COLLECTIONS ON BARROW ISLAND}

The early history of Barrow Island was reviewed by Hook et al. (2004) as part of a cultural heritage assessment of the island; an earlier review by Cox (1977) has unfortunately become difficult to find. The earliest natural history collections on Barrow Island were taken by the HMS Beagle when it landed in 1840, primarily for the purpose of collecting firewood (Wickham 1841). Kangaroo skins collected from Barrow Island by the Beagle were described by Gould (1841) as Osphranter isabellinus (now Macropus robustus isabellinus) and Lagorchestes conspicillatus, but no invertebrates were described from this landing. The Tien Tsin under the command of Capt. Jarman landed on Barrow Island for two days in December 1864 ('Journal of the late voyage of the Tien Tsin', Perth Gazette and West Australian Times, 27 January 1865). Describing the waterless island as 'altogether...the most unpromising looking spot we have found in the N.W. country', Jarman had the island fired 'from end to end', presumably in the hope that doing so might help improve its productivity.
During the late 1800s Barrow Island was utilised at various times by pastoralists, guano miners, pearl and turtle fishers, and slavers (Hook et al. 2004; 'Supreme Court-Civil Side', West Australian, 26 May 1887; 'The native question', Daily News [Perth], 16 February 1905). If any of these individuals were interested in collecting invertebrates, their endeavours in that field have not been recorded for posterity.

J.T. Tunney of the Western Australian Museum spent six weeks on Barrow Island in 1901 ('News and notes', West Australian, 22 March 1901). He was primarily collecting mammals and birds, but fleas and ticks taken from those vertebrates would be the first terrestrial invertebrate records for Barrow Island (Rothschild 1903; Warburton \& Nuttall 1909; Robinson 1926). The publicity from Tunney's vertebrate collections played a part in the declaration of Barrow Island as one of Western Australia's first nature reserves in 1908.

After oil was discovered in Barrow Island on 1964, a mining lease was granted to the West Australian Petroleum Pty (WAPET), who appointed W. H. Butler as their environmental consultant in 1967. Though Butler's own publications were focused on Barrow Island's vertebrate fauna, he also collected invertebrate specimens during his time on the island, a number of which have subsequently been described by other authors. WAPET also sponsored a number of other naturalists for studies on Barrow Island; particularly notable among these from an invertebrate perspective were D. H. Perry in 1971 (publishing on Barrow Island's Isoptera) and C. N. Smithers in 1982 (publishing on Psocoptera, Odonata, Neuroptera and Lepidoptera). Staff from the Western Australian Museum also visited Barrow Island in the late 1990s and following years, collecting arachnids and myriapods (M.S. Harvey 
and associates) and gastropods (S. Slack-Smith).

Offshore natural gas reserves to the north-west of Barrow Island were discovered in 1980, leading to an application to establish a gas production plant on the island. Approval for development of the plant was awarded in 2003, subject to the imposition of various conditions to minimise the plant's impact on Barrow Island's value as a nature reserve. As part of these conditions, a continuing monitoring program for Barrow Island terrestrial invertebrates was begun in 2005 (Callan et al. 2011). Material collected as part of this program has been used in the descriptions of a number of taxa, and work on the material continues today.

TABLE 1 Publication and identification tallies for higher invertebrate taxa on Barrow Island.

\begin{tabular}{|c|c|c|c|}
\hline Taxon & $\begin{array}{l}\text { Number of } \\
\text { publications }\end{array}$ & $\begin{array}{l}\text { Number of named species } \\
\text { recorded from Barrow Island }\end{array}$ & $\begin{array}{l}\text { Number of morphospecies } \\
\text { recorded by Callan et al. (2011) }\end{array}$ \\
\hline Acariformes & 3 & 8 & 81 \\
\hline Araneae & 21 & 52 & 171 \\
\hline Chilopoda & 3 & 7 & 15 \\
\hline Coleoptera & 6 & 24 & 282 \\
\hline Collembola & 2 & 17 & 41 \\
\hline Dictyoptera & 5 & 33 & 49 \\
\hline Diplopoda & 4 & 4 & 3 \\
\hline Diptera & 1 & 3 & 171 \\
\hline Embioptera & 0 & 1 & 1 \\
\hline Gastropoda & 10 & 10 & 12 \\
\hline Hemiptera & 5 & 42 & 246 \\
\hline Hymenoptera & 11 & 86 & 373 \\
\hline Isopoda & 1 & 8 & 14 \\
\hline Lepidoptera & 2 & 61 & 181 \\
\hline Neuroptera & 7 & 30 & 27 \\
\hline Odonata & 1 & 7 & 4 \\
\hline Orthoptera & 0 & 24 & 92 \\
\hline Parasitiformes & 6 & 8 & 17 \\
\hline Phasmatodea & 0 & 4 & 6 \\
\hline Platyhelminthes & 1 & 3 & - \\
\hline Pseudoscorpiones & 3 & 5 & 14 \\
\hline Psocodea & 2 & 7 & 19 \\
\hline Schizomida & 2 & 1 & - \\
\hline Scorpiones & 2 & 2 & 4 \\
\hline Siphonaptera & 2 & 1 & - \\
\hline Strepsiptera & 0 & 1 & 2 \\
\hline Thysanoptera & 7 & 14 & 40 \\
\hline Thysanura & 0 & 1 & 8 \\
\hline Total & $111^{*}$ & 464 & 1873 \\
\hline
\end{tabular}

* Including four general references. 


\section{METHODOLOGY}

Publications were located using online resources, as well as in the library of the Western Australian Museum. Aquatic stygofauna were not included in this survey; for a review of the Barrow Island stygofauna, see Humphreys (2001). I have, however, included publications on non-aquatic troglofauna with relatives in the terrestrial epigean environment. For each publication, a brief note on its relevance to the Barrow Island invertebrate fauna has been appended. Taxa previously described from other locations have been noted as 'recorded from Barrow Island'; new taxa in the publication cited have been noted as 'described from Barrow Island' (if known from Barrow Island material only) or 'described from Barrow Island and mainland Australia' (if material from other localities in Australia was also included in the description). If any relevant publications have been omitted from this bibliography, the author would be grateful to be informed of them.

\section{SUMMARY}

A total of 104 publications were found discussing the Barrow Island invertebrate fauna or commenting on specimens from Barrow Island. The great majority of these had a taxonomic focus. Only two studies were not primarily concerned with either invertebrate taxonomy or taxonomic surveys: Withers et al. (1997) on the physiology of snails during aestivation, and Abdad (2011) on transmission of Rickettsia by ticks.

Table 1 compares the publication effort for each major invertebrate group with the potential number of species on Barrow Island. For convenience, the number of morphospecies recorded by Callan et al. (2011) has been used as a proxy for the true diversity, though in most (if not all) cases the former will be more or less lower than the latter. The tally of formally named species recorded on Barrow Island for each group includes those listed in the electronic appendices from Callan et al. (2011); those records that were only provisionally attributed to formal species therein have been included in the tally.

A number of smaller invertebrate groups appear to have been reasonably well studied relative to their diversity, in particular Diplopoda and terrestrial Gastropoda (with the highest number of publications relative to recorded morphospecies), and Neuroptera and Odonata (with the highest proportions of species identified to formally named taxa). Amongst the larger groups (with over 100 morphospecies), the Araneae have been the most extensively published on, though Lepidoptera include a slightly higher proportion of formally named species. Particularly poorly surveyed are the
Barrow Island Diptera, of which only three species (two of them mosquitoes) have been identified in press to named species.

Preliminary results suggest that endemism on Barrow Island is relatively low. Of 464 formally named species recorded from the island, only 40 $(9 \%)$ have not been recorded from other localities (including Quistrachia barrowensis Solem, 1997, which is known from adjacent islets only, and Draculoides bramstokeri Harvey \& Humphreys, 1995, for which supposed mainland populations have been reidentified as a distinct species). Though this may change as more currently unnamed species become formally recognised, there is no reason to assume the rate of endemism will go up. Indeed, the current value may well be an overestimate, as our ability to assess Barrow Island's fauna in this regard is limited not only by our knowledge of Barrow Island itself, but also by our restricted knowledge of faunas in adjacent regions of the Australian mainland.

\section{ACKNOWLEDGEMENTS}

Thanks are due to Jonathan Majer (Curtin University) who suggested the compilation of this bibliography; to Mark Harvey (Western Australian Museum) and Nihara Gunawardene (Curtin University) for their work in putting together this special issue; and to the staff of the Curtin University and Western Australian Museum libraries for their supply of resources utilised in locating the publications cited.

\section{BIBLIOGRAPHY}

\section{GENERAL REFERENCES}

Callan, S.K., Majer, J.D., Edwards, K. and Moro, D. (2011). Documenting the terrestrial invertebrate fauna of Barrow Island, Western Australia. Australian Journal of Entomology 50: 323-343.

Summarises the 2005-2009 surveys of terrestrial invertebrates on Barrow Island.

Cox, J.M. (1977). Barrow Island: An historical documentation. Privately published, Perth, Western Australia.

Davidovitch, L., Stoklosa, R., Majer, J., Nietrzeba, A., Whittle, P., Mengersen, K. and Ben-Haim, Y. (2009). Info-gap theory and robust design of surveillance for invasive species: the case study of Barrow Island. Journal of Environmental Management 90: 2785-2793.

Describes the development of the monitoring system for potential invasive invertebrates on Barrow Island; utilises Pheidole megacephala (Fabricius, 1793) (Hymenoptera: Formicidae) as an exemplar.

Gould, J. (1841). Descriptions of four new species of kangaroo. Proceedings of the Zoological Society of London 1841: 80-83.

Heatwole, H. (1978). Ants under investigation. WAPET Journal 1978: 28-29. 
Popular article on insect collection methods used on Barrow Island by $\mathrm{H}$. Heatwole.

Hook, F., McDonald, E., Paterson, A., Souter, C. \& Veitch, B. (2004). Cultural heritage assessment and management plan-proposed Gorgon development, Pilbara, north Western Australia. Report compiled for Environmental Resources Management Australia Pty Ltd \& Chevron Texaco Australia Pty Ltd, 75 pp.

Humphreys, W.F. (2001). The subterranean fauna of Barrow Island, northwestern Australia, and its environment. Mémoire de Biospéologie 26: 108-127.

Smith, J.A., Wright, L.J. and Morris, K.D. (2006). BiblioBarrowIsland-an annotated bibliography of the natural history of Barrow Island 1622-2004. Conservation Science Western Australia 5: 296-364.

Whittle, P.J.L., Stoklosa, R., Barrett, S., Jarrad, F.C., Majer, J.D., Martin, P.A.J. and Mengersen, K. (2013). A method for designing complex biosecurity surveillance systems: detecting non-indigenous species of invertebrates on Barrow Island. Diversity and Distributions 19: 629-639.

Wickham, J.C. (1841). Proceedings of H.M.S. Beagle. Nautical Magazine and Naval Chronicle 1841: 438-444.

\section{ACARIFORMES}

Otto, J.C. (1999). Revision of the genus Erythracarus Berlese (Acarina: Anystidae: Erythracarinae). Journal of Natural History 33: 825-909.

Erythracarus decoris n. sp. described from Barrow Island and mainland Australia.

Southcott, R.V. (1972). Revision of the larvae of the tribe Callidosomatini (Acarina: Erythraeidae) with observations on post-larval instars. Australian Journal of Zoology, Supplementary Series 13: 1-84.

Caeculisoma cooremani n. sp. described from Barrow Island, Montebello Islands and Western Australia; Caeculisoma darwiniense Southcott, 1961 recorded from Barrow Island.

Wallace, M.M.H. and Mahon, J.A. (1972). The taxonomy and biology of Australian Bdellidae (Acari). I. Subfamilies Bdellinae, Spinibdellinae and Cytinae. Acarologia 14: 544-580.

Biscirus arenarius n. sp. described from Barrow Island (as 'Barrows Is.') and Western Australia.

\section{ARANEAE}

Baehr, B. and Jocqué, R. (2000). Revisions of genera in the Asteron-complex (Araneae: Zodariidae). The new genera Cavasteron and Minasteron. Records of the Western Australian Museum 20: 1-30.

Minasteron minusculum n. sp. described from Barrow Island and Western Australia.

Crews, S.C. and Harvey, M.S. (2011). The spider family Selenopidae (Arachnida, Araneae) in Australasia and the Oriental region. ZooKeys 99: 1-103.

Karaops burbidgei n. sp. described from Barrow Island.

Davies, V.T. (1994). The huntsman spiders Heteropoda Latreille and Yinthi gen. nov. (Araneae: Heteropodidae) in Australia. Memoirs of the Queensland Museum 35: 75-122.

Heteropoda hermitis (Hogg, 1914) recorded from Barrow Island.
Framenau, V.W. (2006). Knoelle, a new monotypic spider genus from Australia (Araneae: Lycosidae). Zootaxa 1281: 55-67.

Knoelle clara (Koch, 1877) recorded from Barrow Island.

Framenau, V.W. (2011). Lariniophora, a new monotypic orb-weaving spider genus from Australia (Araneae: Araneidae: Araneinae). Records of the Western Australian Museum 26: 191-201.

Lariniophora ragnhildae (Strand, 1917) recorded from Barrow Island.

Framenau, V.W., Dupérré, N., Blackledge, T.A. and Vink, C.J. (2010). Systematics of the new Australasian orb-weaving spider genus Backobourkia (Araneae: Araneidae: Araneinae). Arthropod Systematics and Phylogeny 68: 79-111.

Backobourkia collina (Keyserling, 1886) recorded from Barrow Island and Montebello Islands.

Framenau, V.W. and Scharff, N. (2008). The orbweaving spider genus Larinia in Australia (Araneae: Araneidae). Arthropod Systematics and Phylogeny 66: 227-250.

Larinia montagui Hogg, 1914 recorded from Barrow Island.

Harvey, M.S., Austin, A.D. and Adams, M. (2007). The systematics and biology of the spider genus Nephila (Araneae: Nephilidae) in the Australasian region. Invertebrate Systematics 21: 407-451.

Nephila edulis (Labillardière, 1799) recorded from Barrow Island.

Hirst, D.B. (1998). Irileka, a new heteropodine genus (Araneae: Heteropodidae) from Western Australia. Records of the Western Australian Museum 19: 141-144.

Irileka iridescens $\mathrm{n}$. sp. described from Barrow Island and Western Australia.

Huber, B.A. (2001). The pholcids of Australia (Araneae; Pholcidae): taxonomy, biogeography, and relationships. Bulletin of the American Museum of Natural History 260: 1-144.

Trichocyclus nigropunctatus Simon, 1908 recorded from Barrow Island; T. aranda n. sp. described from Barrow Island, Western Australia and Northern Territory.

Langlands, P.R. and Framenau, V.W. (2010). Systematic revision of Hoggicosa Roewer, 1960, the Australian 'bicolor' group of wolf spiders (Araneae: Lycosidae). Zoological Journal of the Linnean Society 158: 83-123.

Lycosa snelli McKay, 1975 transferred to Hoggicosa, and recorded from localities outside Barrow Island.

McKay, R.J. (1975). The wolf spiders of Australia (Araneae: Lycosidae): 5. Two new species of the bicolor group. Memoirs of the Queensland Museum 17: 313-318.

Lycosa snelli $\mathrm{n}$. sp. described from Barrow Island.

Ott, R. and Harvey, M.S. (2008). A new species of Pelicinus from Barrow Island, Western Australia (Araneae: Oonopidae). Arthropoda Selecta 17: 81-85.

Pelicinus saaristoi n. sp. described from Barrow Island.

Platnick, N.I. (2000). A relimitation and revision of the Australasian ground spider family Lamponidae (Araneae: Gnaphosoidea). Bulletin of the American Museum of Natural History 245: 1-330.

Lampona barrow n. sp. described from Barrow Island; Lamponina scutata (Strand, 1913) recorded from Barrow Island.

Platnick, N.I. (2002). A revision of the Australasian 
ground spiders of the families Ammoxenidae, Cithaeronidae, Gallieniellidae, and Trochanteriidae (Araneae: Gnaphosoidea). Bulletin of the American Museum of Natural History 271: 1-243.

Barrowammo waldockae n. gen, n. sp. and Fissarena barrow n. sp. described from Barrow Island; Meedo houstoni Main, 1987 and Morebilus diversus (Koch, 1875) recorded from Barrow Island.

Platnick, N.I. and Baehr, B. (2006). A revision of the Australasian ground spiders of the family Prodidomidae (Araneae: Gnaphosoidea). Bulletin of the American Museum of Natural History 298: 1-297.

Prodidomus woodleigh n. sp., Wyundra barrow n. sp. and Nomindra leeuweni n. sp. described from Barrow Island and mainland Australia; Cryptoerithus occultus Rainbow, 1915 recorded from Barrow Island.

Raven, R.J. (1994). Mygalomorph spiders of the Barychelidae in Australia and the western Pacific. Memoirs of the Queensland Museum 35: 291-706.

Synothele butleri n. sp. described from Barrow Island.

Rix, M.G., Harvey, M.S. and Roberts, J.D. (2010). A revision of the textricellin spider genus Raveniella (Araneae: Araneoidea: Micropholcommatidae): exploring patterns of phylogeny and biogeography in an Australian biodiversity hotspot. Invertebrate Systematics 24: 209-237.

Unidentified specimens of Raveniella recorded from Barrow Island.

Smith, H.M. (2006). A revision of the genus Poltys in Australasia (Araneae: Araneidae). Records of the Australian Museum 58: 43-96.

Poltys illepidus Koch, 1843 recorded from Barrow Island.

abka, M. (1994). Salticidae (Arachnida: Araneae) of Oriental, Australian and Pacific regions, X. Genus Simaetha Thorell. Records of the Western Australian Museum 16: 499-534.

Simaetha tenuior (Keyserling, 1882) recorded from Barrow Island.

abka, M., and Waldock, J. (2012). Salticidae (Arachnida: Araneae) from Oriental, Australian and Pacific regions. Genus Cosmophasis Simon, 1901. Annales Zoologici 62: 115-198.

Cosmophasis baehrae n. sp. described from Barrow Island (type locality), Western Australia, Northern Territory and Indonesia.

\section{CHILOPODA}

Edgecombe, G.D. and Barrow, L. (2007). A new genus of scutigerid centipedes (Chilopoda) from Western Australia, with new characters for morphological phylogenetics of Scutigeromorpha. Zootaxa 1409: 23-50.

Pilbarascutigera incola (Verhoeff, 1925) recorded from Barrow Island.

Koch, L.E. (1983a). Morphological characters of Australian scolopendrid centipedes, and the taxonomy and distribution of Scolopendra morsitans L. (Chilopoda: Scolopendridae: Scolopendrinae). Australian Journal of Zoology 31: 79-91.

Scolopendra morsitans Linnaeus, 1758 recorded from Barrow Island.

Koch, L.E. (1983b). Revision of the Australian centipedes of the genus Cormocephalus Newport (Chilopoda: Scolopendridae: Scolopendrinae). Australian Journal of Zoology 31: 799-833.

Cormocephalus strigosus Kraepelin, 1908 recorded from Barrow Island.

\section{COLEOPTERA}

Bellés, X. (1998). A new subgenus and two new species of Sphaericus (Coleoptera: Ptinidae) from Western Australia. European Journal of Entomology 95: 263-268.

Sphaericus (Leasphaericus) flavipennis n. sp. described from Barrow Island and Cape Range, Western Australia.

Freitag, R. (1979). Reclassification, phylogeny and zoogeography of the Australian species of Cicindela (Coleoptera: Cicindelidae). Australian Journal of Zoology, Supplementary Series 66: 1-99.

Cicindela rafflesia Chaudoir, 1852 recorded from Barrow Island

Kejval, Z. (2009). Taxonomic revision of the genus Chileanthicus Werner (Coleoptera: Anthicidae). Zootaxa 2180: 1-82.

Chileanthicus exul n. sp. described from Barrow Island.

Matthews, E.G. (1972). A revision of the scarabaeine dung beetles of Australia. I. Tribe Onthophagini. Australian Journal of Zoology, Supplementary Series 9: 1-330.

Onthophagus murchisoni Blackburn, 1892 and O. parvus Blanchard, 1853 recorded from Barrow Island, the latter recorded in association with spectacled hare wallaby, Lagorchestes conspicillatus.

Matthews, E.G. (1974). A revision of the scarabaeine dung beetles of Australia. II. Tribe Scarabaeini. Australian Journal of Zoology, Supplementary Series 24: 1-211.

Tesserodon tenebroides n. sp. described from Barrow Island.

Scholtz, C.H. (1986). Revision of the genus Trox Fabricius (Coleoptera: Trogidae) of the Australasian region. Australian Journal of Zoology, Supplementary Series 125: 1-99.

Trox dilaticollis Macleay, 1888, T. strzeleckensis Blackburn, 1895 and Trox euclensis Blackburn, 1892 recorded from Barrow Island.

\section{COLLEMBOLA}

Greenslade, P. (2008). Has survey effort of Australia's islands reflected conservation and biogeographical significance? An assessment using Collembola. European Journal of Soil Biology 44: 458-462.

Collection effort on Barrow Island for Collembola compared to that of other Australian islands.

Zhang, F., Deharveng, L., Greenslade, P. and Chen, J.X. (2009). Revision of Acanthocyrtus (Collembola: Entomobryidae), with description of a new genus from eastern Asia. Zoological Journal of the Linnean Society 157: 495-514.

Acanthocyrtus barrowensis Zhang n. sp. described from Barrow Island.

\section{DICTYOPTERA}

Mackerras, M.J. (1968). Australian Blattidae (Blattodea). VIII. The Platyzosteria group; subgenus Melanozosteria Stål. Australian Journal of Zoology 16: 237-331.

Platyzosteria sublobata (Princis, 1954) recorded from Barrow Island and Montebello Island. 
Perry, D.H. (1972). Some notes on the termites (Isoptera) of Barrow Island and a check list of species. Western Australian Naturalist 12: 419-425.

Fifteen named species and ten undescribed species of termite recorded for Barrow Island.

Roth, L.M. (1990). A revision of the Australian Parcoblattini (Blattaria: Blattellidae: Blattellinae). Memoirs of the Queensland Museum 28: 531-596.

Paratemnopteryx australis Saussure, 1869 recorded from Barrow Island.

Roth, L.M. (1995). New species and records of cockroaches from Western Australia (Blattaria). Records of the Western Australian Museum 17: 153-161.

Unidentified specimens of Nocticola recorded from Barrow Island.

Watson, J.A.L. and Perry, D.H. (1981). The Australian harvester termites of the genus Drepanotermes (Isoptera: Termitinae). Australian Journal of Zoology, Supplementary Series 78: 1-153.

Drepanotermes basidens n. sp., D. calabyi n. sp., D. dibolia n. sp. and D. diversicolor n. sp. described from Barrow Island and mainland Australia; D. rubriceps (Froggatt, 1898) recorded from Barrow Island.

\section{DIPLOPODA}

Car, C.A. and Harvey, M.S. (2013). A review of the Western Australian keeled millipede genus Boreohesperus (Diplopoda, Polydesmida, Paradoxosomatidae). ZooKeys 290: 1-19.

Boreohesperus dubitalis n. sp. described from Barrow Island.

Hoffman, R.L. (1994). Studies on spiroboloid millipeds. XVIII. Speleostrophus nesiotes, the first known troglobitic spiroboloid millipede, from Barrow Island, Western Australia (Diplopoda: Pachybolidae: Trigoniulinae). Myriapodologica 3: 19-24.

Speleostrophus nesiotes n. gen., n. sp. described from Barrow Island.

Short, M. and Huynh, C. (2009). Phryssonotus novaehollandiae Silvestri, 1923: the sole Australian representative of the millipede family Synxenidae. Soil Organisms 81: 695-700.

Phryssonotus novaehollandiae Silvestri, 1923 recorded from Barrow Island.

Short, M. and Huynh, C. (2011). The genus Unixenus Jones, 1944 (Diplopoda, Penicillata, Polyxenida) in Australia. ZooKeys 156: 105-122.

Unixenus mjoebergi (Verhoeff, 1924) recorded from Barrow Island.

\section{DIPTERA}

Munari, L. (2004). Beach flies (Diptera: Tethinidae: Tethininae) from Australia and Papua New Guinea, with descriptions of two new genera and ten new species. Records of the Australian Museum 56: 29-56.

Thitena cadaverina n. gen., n. sp. described from Barrow Island.

\section{GASTROPODA}

Butler, W.H. (1975). Additions to the fauna of Barrow Island, W. A. Western Australian Naturalist 13: 78-80.
Rhagada convicta (Cox, 1870) recorded from Barrow Island.

Frias Martins, A. M. de. (1995). Systematic revision of Allochroa Ancey, 1887 (Pulmonata: Ellobiidae), with an account of the anatomy of Allochroa layardi (H. \& A. Adams, 1855) and the description of two new species. The Nautilus 109: 1-13.

Allochroa layardi (H. \& A. Adams, 1855) recorded from Barrow Island.

Johnson, M.S., Hamilton, Z.R. and Fitzpatrick, J. (2006). Genetic diversity of Rhagada land snails on Barrow Island. Journal of the Royal Society of Western Australia 89: $45-50$.

Allozyme diversity of Barrow Island Rhagada analysed; identification of the two species found on Barrow Island discussed. The larger species on Barrow Island has been identified as $R$. convicta (Butler 1975; Callan et al. 2011) or R. tescorum Benson, 1853 (Withers et al. $1997)$ and the smaller species compared to $R$. plicata Preston, 1914, but Johnson et al. $(2006,2012)$ treat both as not identified with any formally named species.

Johnson, M.S., Hamilton, Z.R., Teale, R. and Kendrick, P.G. (2012). Endemic evolutionary radiation of Rhagada land snails (Pulmonata: Camaenidae) in a continental archipelago in northern Western Australia. Biological Journal of the Linnean Society 106: 316-327.

Places the Barrow Island Rhagada species in a phylogenetic context.

Solem, A. (1986). Pupilloid land snails from the south and mid-west coasts of Australia. Journal of the Malacological society of Australia 7: 95-124.

Gastrocopta deserti Pilsbry, 1917, Pupoides contrarius (Smith, 1894) and P. lepidulus (Adams \& Angas, 1864) recorded from Barrow Island.

Solem, A. (1988). Non-camaenid land snails of the Kimberley and Northern Territory, Australia. I. Systematics, affinities and ranges. Invertebrate Taxonomy 4: 455-604.

Gastrocopta deserti Pilsbry, 1917 recorded from Barrow Island.

Solem, A. (1997). Camaenid land snails from Western and central Australia (Mollusca: Pulmonata: Camaenidae). VII. Taxa from Dampierland through the Nullarbor. Records of the Western Australian Museum, Supplement 50: 1461-1906.

Quistrachia barrowensis n. sp. described from Barrow Island and nearby islets.

Wells, F.E. (1997). A review of the northern Australian species of the genera Cassidula and Ellobium (Gastropoda: Ellobiidae). In: Hanley, J.R., Caswell, G., Megirian, D. and Larson, H.K. (eds) Proceedings of the Sixth International Marine Biological Workshop. The marine flora and fauna of Darwin Harbour, Northern Territory, Australia, pp. 213-229. Museums and Art Galleries of the Northern Territory and the Australian Marine Sciences Association, Darwin.

Cassidula aurisfelis (Bruguière, 1789) recorded from Barrow Island.

Whisson, C.S. and Köhler, F. (2012). Gastrocopta (Mollusca, Gastropoda, Pupillidae) in the Pilbara region of Western Australia. ZooKeys 261: 15-39.

Gastrocopta mussoni Pilsbry, 1917 (including Gastrocopta deserti as synonym) and 'Gastrocopta sp. CW1' recorded from Barrow Island. 
Withers, P., Pedler, S. and Guppy, M. (1997). Physiological adjustments during aestivation by the Australian land snail Rhagada tescorum (Mollusca: Pulmonata: Camaenidae). Australian Journal of Zoology 45: 599-611.

Aestivation of Rhagada specimens collected on Barrow Island induced in the laboratory and physiological responses measured.

\section{HEMIPTERA}

Fletcher, M.J. (2007). The identity of Pascoepus viridiceps (Evans) based on recognition of the male and a new species of Zaletta from Barrow Island, Western Australia (Hemiptera: Cicadellidae: Idiocerinae). General and Applied Entomology 36: 13-16.

Zaletta webbi n. sp. described and Pascoepus viridiceps (Evans, 1942) recorded from Barrow Island.

Fletcher, M.J. (2008). An impressive new species of Euacanthella Evans from Western Australia (Hemiptera: Cicadellidae: Euacanthellinae). General and Applied Entomology 37: 15-19.

Euacanthella impressa n. sp. described from Barrow Island.

Fletcher, M.J. (2009). A new species of deltocephaline leafhoppers of the genus Horouta from Barrow Island, Western Australia (Hemiptera: Cicadellidae). Records of the Western Australian Museum 25: 265-268.

Horouta darwini n. sp. described from Barrow Island.

Lansbury, I. (1969). The genus Anisops in Australia (Hemiptera-Heteroptera, Notonectidae). Journal of Natural History 3: 433-458.

Anisops stali Kirkaldy, 1904 recorded from Barrow Island (cited as 'Barrow D', collected by W. H. Butler).

Smithers, C.N. (1985). New records of Pogonella bispinus (Stål) (Homoptera: Membracidae) from eastern Australia and Barrow Island, Western Australia. Australian Entomological Magazine 12: 35-36.

Pogonella bispinus (Stål, 1869) recorded from Barrow Island.

\section{HYMENOPTERA}

Evans, H.E. (1976). A revision of spider wasps of the genus Ctenostegus (Hymenoptera: Pompilidae). Australian Journal of Zoology, Supplementary Species 43: 1-107.

Ctenostegus albiceps n. sp. described from Barrow Island.

Gunawardene, N.R., and Taylor, C.K. (2012). New records of Elasmus (Hymenoptera, Eulophidae) species from Barrow Island, Western Australia. Journal of Hymenoptera Research 29: 21-35.

Elasmus curticornis n. sp. described from Barrow Island; ten further species of Elasmus recorded from Barrow Island.

Heterick, B.E. (2009). A guide to the ants of south-western Australia. Records of the Western Australian Museum, Supplement 76: 1-206.

Paratrechina longicornis (Latreille, 1802), Polyrhachis ammonoeides Roger, 1863 and Leptanilla swani Wheeler, 1932 noted as recorded from Barrow Island.

Reyes, S.G. (1993). Revision of the bee genus Braunsapis in the Australian region (Hymenoptera: Xylocopinae: Allodapini). University of Kansas Science Bulletin 55: 97-122.
Braunsapis plebeia (Cockerell, 1929) recorded from Barrow Island.

Shattuck, S.O. (1993). Revision of the Iridomyrmyx purpureus species-group (Hymenoptera: Formicidae). Invertebrate Taxonomy 7: 113-149.

Iridomyrmex sanguineus Forel, 1910 recorded from Barrow Island.

Shattuck, S.O. (1996). Revision of the Iridomyrmex discors species-group (Hymenoptera: Formicidae). Australian Journal of Entomology 35: 37-42.

Iridomyrmex discors Forel, 1902 recorded from Barrow Island.

Shattuck, S.O. (2008). Review of the ant genus Aenictus (Hymenoptera: Formicidae) in Australia with notes on A. ceylonicus (Mayr). Zootaxa 1926: 1-19.

Aenictus turneri Forel, 1900 recorded from Barrow Island.

Shattuck, S.O., Gunawardene, N.R. and Heterick, B. (2012). A revision of the ant genus Probolomyrmex (Hymenoptera: Formicidae: Proceratiinae) in Australia and Melanesia. Zootaxa 3444: 40-50.

Probolomyrmex latalongus n. sp. described from Barrow Island and mainland Australia.

Shattuck, S.O. and Slipinska, E. (2012). Revision of the Australian species of the ant genus Anochetus (Hymenoptera: Formicidae). Zootaxa 3426: 1-28.

Anochetus rectangularis Mayr, 1876 recorded from Barrow Island.

Taylor, R.W. (1989). The nomenclature and distribution of some Australian ants of the genus Polyrhachis Fr Smith (Hymenoptera: Formicidae: Formicinae). Journal of the Australian Entomological Society 28: 23-27.

Polyrhachis inconspicua Emery, 1887 recorded from Barrow Island.

Taylor, R.W. (1990). The nomenclature and distribution of some Australian and New Caledonian ants of the genus Meranoplus Fr. Smith (Hymenoptera: Formicidae: Myrmicinae). General and Applied Entomology 22: 31-40.

Meranoplus dimidiatus Smith, 1867 recorded from Barrow Island.

\section{ISOPODA}

Dalens, H. (1993). Two new genera of terrestrial isopods (Crustacea: Isopoda: Oniscidea) from north-western Western Australia. Records of the Western Australian Museum 16: 257-267.

Ligia exotica Roux, 1828 and Laevophiloscia yalgoonensis Wahrberg, 1922 recorded from Barrow Island; Barrowdillo pseudopyrgoniscus n. gen., n. sp. described from Barrow Island.

\section{LEPIDOPTERA}

Grund, R. (1996). The distribution of Theclinesthes albocincta (Waterhouse) and Theclinesthes hesperia Sibitani \& Grund, based on herbarium records of eggs (Lepidoptera: Lycaenidae). Australian Entomologist 23: 101-110.

Theclinesthes albocincta (Waterhouse, 1903) recorded from Barrow Island.

Smithers, C.N. and Butler, W.H. (1983). The butterflies (Lepidoptera: Hesperioidea and Papilionoidea) 
of Barrow and nearby islands, Western Australia. Western Australian Naturalist 15: 141-145.

Fourteen named species recorded from Barrow Island.

\section{NEUROPTERA}

Lambkin, K.J. (1986). A revision of the Australian Mantispidae (Insecta: Neuroptera) with a contribution to the classification of the family. I. General and Drepanicinae. Australian Journal of Zoology, Supplementary Series 116: 1-142.

Theristria tillyardi Handschin, 1935 recorded from Barrow Island.

New, T.R. (1980). A revision of the Australian Chrysopidae (Insecta: Neuroptera). Australian Journal of Zoology, Supplementary Series 77: 1-143.

Chrysopa ramburi Schneider, 1851 and C. signata Schneider, 1851 recorded from Barrow Island.

New, T.R. (1984). Revision of the Australian Ascalaphidae (Insecta: Neuroptera). Australian Journal of Zoology, Supplementary Series 100: 1-86.

Suhpalacsa barrowensis n. sp. described from Barrow Island.

New, T.R. (1985a). A revision of the Australian Myrmeleontidae (Insecta: Neuroptera). I. Introduction, Myrmeleontini, Protoplectrini. Australian Journal of Zoology 104: 1-90.

Myrmeleon pallidus (Esben-Petersen, 1918) recorded from Barrow Island.

New, T.R. (1985b). A revision of the Australian Myrmeleontidae (Insecta: Neuroptera). III. Distoleontini and Acanthaclisinae. Australian Journal of Zoology, Supplementary Series 106: 1-159.

Eophanes distinctus (Banks, 1939), Heoclisis fundata (Walker, 1853) and $H$. acuta (Kimmins, 1939) recorded from Barrow Island.

Smithers, C.N. (1984). The Neuroptera of Barrow and nearby islands off the west coast of Western Australia. Australian Entomological Magazine 11: 61-68.

Barrowiella butleri n. gen., n. sp. described from Barrow Island; Cryptoscenea evansorum n. sp. described from Barrow Island and Western Australia; eight further named species recorded from Barrow Island.

Smithers, C.N. (1988). Four additional antlion records from Barrow Island, Western Australia (Neuroptera: Myrmeleontidae). Australian Entomological Magazine 15: 2.

Heoclisis conspurcata (Gerstaecker, 1885), Cosina mclachlani (Weele, 1903), Mestressa subfasciata (Banks, 1913) and Bandidus nr congestus (Gerstaecker, 1885) recorded from Barrow Island.

\section{ODONATA}

Smithers, C.N. and Butler, W.H. (1985). Dragonflies and damselflies (Odonata) from Barrow and nearby islands off the coast of Western Australia. Australian Entomological Magazine 12: 9-12.

Ischnura aurora (Brauer, 1865), Hemianax papuensis (Burmeister, 1839), Pantala flavescens (Fabricius, 1798), Trapezostigma loewi Brauer, 1866, Macrodiplax cora (Kaup, 1867) and Diplacodes bipunctata (Brauer, 1865) recorded from Barrow Island.

\section{PARASITIFORMES}

Abdad, M.Y. (2011). An epidemiological and serological study of Rickettsia in Western Australia. PhD thesis, Murdoch University.

Role of Amblyomma triguttatum Koch, 1844 and Ixodes australiensis Neumann, 1904 in transmission of rickettsiae investigated on Barrow Island and other localities in Western Australia. Ixodes australiensis newly recorded from Barrow Island.

Domrow, R. (1980). Some laelapine parasites of Australasian mammals (Acari: Dermanyssidae). Records of the Western Australian Museum 8: 207-235.

Mesolaelaps antipodianus (Hirst, 1926) and Haemolaelaps marsupialis (Berlese, 1910) recorded as parasites on golden bandicoot, Isoodon auratus.

Roberts, F.H.S. (1962). On the status of morphologically divergent tick populations of Amblyomma triguttatum Koch (Acarina: Ixodidae). Australian Journal of Zoology 10: 367-381.

Amblyomma triguttatum triguttatum Koch, 1844 recorded from Barrow Island; Amblyomma triguttatum ornatissimum n. ssp. named from Barrow Island (type locality) and mainland Australia, on the basis of 'Amblyomma triguttatum var.' of Robinson (1926).

Robinson, L.E. (1926). Monograph of the Ixodoidea pt. 4. The genus Amblyomma. Cambridge University Press:, London, xii +302 pp, 7 pls.

Amblyomma triguttatum Koch, 1844 recorded from Barrow Island ('off kangaroo'). Specimens from Barrow Island and central Queensland distinguished as 'Amblyomma triguttatum var.', later named $A$. triguttatum ornatissimum by Roberts (1962).

Smyth, M. (1973). The distribution of three species of reptile ticks, Aponomma hydrosauri (Denny), Amblyomma albolimbatum Neumann, and Amb. limbatum Neumann. Australian Journal of Zoology 21: 91-101.

Amblyomma limbatum Neumann, 1899 recorded from Barrow Island and Lowendal Island.

Warburton, C. and Nuttall, G.H.F. (1909). On new species of Ixodidae, with a note on abnormalities observed in ticks. Parasitology 2: 57-76.

Haemaphysalis humerosa n. sp. described from 'Perameles macrura'. Bandicoots on Barrow Island have since been reidentified as the golden bandicoot, I. auratus.

\section{PLATYHELMINTHES}

Beveridge, I. and Thompson, R.C.A. (1979). The anoplocephalid cestode parasites of the spectacled hare-wallaby, Lagorchestes conspicillatus Gould, 1842 (Marsupialia: Macropodidae). Journal of Helminthology 53: 153-160.

Progamotaenia gynandrolinearis n. sp. described and $P$. lagorchestis (Lewis, 1914) and P. villosa (Lewis, 1914) recorded from Lagorchestes conspicillatus on Barrow Island.

\section{PSEUDOSCORPIONES}

Edward, K.L. and Harvey, M.S. (2008). Short-range endemism in hypogean environments: the pseudoscorpion genera Tyrannochthonius and 
Lagynochthonius (Pseudoscorpiones: Chthoniidae) in the semiarid zone of Western Australia. Invertebrate Systematics 22: 259-293.

Tyrannochthonius aridus n. sp. described from Barrow Island and Western Australia; T. garthhumphreysi n. sp. described from Barrow Island.

Harvey, M.S. and Edward, K.L. (2007). A review of the pseudoscorpion genus Ideoblothrus (Pseudoscorpiones, Syarinidae) from western and northern Australia. Journal of Natural History 41: 445-472.

Ideoblothrus nesotymbus n. sp. described from Barrow Island.

Muchmore, W.B. (1982). The genus Anagarypus (Pseudoscorpionida: Garypidae). Pacific Insects 24: 159-163.

Anagarypus heatwolei n. sp. described from Barrow Island.

\section{PSOCODEA}

Gunawardene, N.R., Taylor, C.K. and Majer, J.D. (2012). Revisiting the Psocoptera (Insecta) of Barrow Island, Western Australia. Australian Entomologist 39: 253-260.

Dorypteryx domestica (Smithers 1958), Liposcelis bostrychophila Badonnel 1931, Ectopsocus nr erosus (Enderlein 1903) and eighteen undescribed species recorded from Barrow Island.

Smithers, C.N. (1984). The Psocoptera of Barrow and Boodie Islands, Western Australia. Entomologica Scandinavica 15: 215-226.

Peripsocus fici n. sp., Cladioneura foliata n. sp. and Barrowia insularis n. gen., n. sp. described and Liposcelis entomophila (Enderlein, 1907) recorded from Barrow Island.

\section{SCHIZOMIDA}

Harvey, M.S., Berry, O., Edward, K.L. and Humphreys, G. (2008). Molecular and morphological systematics of hypogean schizomids (Schizomida: Hubbardiidae) in semiarid Australia. Invertebrate Systematics 22: 167-194.

Draculoides bramstokeri Harvey \& Humphreys, 1995 established as a Barrow Island endemic.

Harvey, M.S. and Humphreys, W.F. (1995). Notes on the genus Draculoides Harvey (Schizomida: Hubbardiidae), with the description of a new troglobitic species. Records of the Western Australian Museum, Supplement 52: 183-189.

Draculoides bramstokeri n. sp. described from Barrow Island and Cape Range, Western Australia.

\section{SCORPIONES}

Volschenk, E.S., Harvey, M.S. and Prendini, L. (2012). A new species of Urodacus (Scorpiones: Urodacidae) from Western Australia. American Museum Novitates 3748: $1-18$

Urodacus butleri n. sp. described from Barrow Island and Western Australia.

Volschenk, E. and Prendini, L. (2008). Aops oncodactylus, gen. et sp. nov., the first troglobitic urodacid (Urodacidae: Scorpiones), with a reassessment of cavernicolous, troglobitic and troglomorphic scorpions. Invertebrate Systematics 22: 235-257.

Aops oncodactylus n. gen., n. sp. described from Barrow Island.

\section{SIPHONAPTERA}

Rothschild, N.C. (1903). Further contributions to the knowledge of the Siphonaptera. Novitates Zoologicae 10: 317-325.

Stephanocircus thomasi n. sp. described from Barrow Island on Mus ferculinus.

Rothschild, N.C. (1911). Some new genera and species of Siphonaptera. Novitates Zoologicae 18: 117-122.

Stephanopsylla n. gen. established for Stephanocircus thomasi Rothschild, 1903.

\section{THYSANOPTERA}

Mound, L.A. (2007). New Australian spore-feeding Thysanoptera (Phlaeothripidae: Idolothripinae). Zootaxa 1604: 53-68.

Priesneriella citricauda Hood, 1927 recorded from Barrow Island.

Mound, L.A., and Masumoto, M. (2009). Australian Thripinae of the Anaphothrips genus-group (Thysanoptera), with three new genera and thirtythree new species. Zootaxa 2042: 1-76.

Anaphothrips barrowi n. sp. and A. callani n. sp. described from Barrow Island and Western Australia.

Mound, L.A. and Minaei, K. (2006). New fungus-feeding thrips (Thysanoptera-Phlaeothripinae) from tropical Australia. Zootaxa 1150: 1-17.

Majerthrips barrowi n. gen., n. sp., Senithrips psomus n. gen., n. sp. and Jacotia rhodorcha n. sp. described from Barrow Island.

Mound, L.A. and Minaei, K. (2007). Australian thrips of the Haplothrips lineage (Insecta: Thysanoptera). Journal of Natural History 41: 2919-2978.

Podothrips anomalus n. sp. described from Barrow Island and Western Australia, P. barrowi n. sp. described from Barrow Island.

Mound, L.A. and Tree, D.J. (2009). Identification and host-plant associations of Australian Sericothripinae (Thysanoptera, Thripidae). Zootaxa 1983: 1-22.

Neohydatothrips barrowi n. sp. described from Barrow Island.

Pereyra, V. and Mound, L.A. (2009). Phylogenetic relationships within the genus Cranothrips (Thysanoptera, Melanthripidae) with consideration of host associations and disjunct distributions within the family. Systematic Entomology 34: 151-161.

Cranothrips kartus Mound, 1972 recorded from Barrow Island.

Pereyra, V. and Mound, L.A. 2010. Phylogenetic relationships within the genus Desmothrips (Thysanoptera, Aeolothripidae), an Australian genus of facultative flower-living predators. Systematic Entomology 35: 306-317.

Desmothrips barrowi n. sp. described from Barrow Island.

MANUSCRIPT RECEIVED 10 DECEMBER 2012: ACCEPTED 30 APRIL 2013 


\section{ADDENDUM}

While this paper was in press, the following publications were brought to my attention:

Heterick, B.E. and Shattuck, S. (2011). Revision of the ant genus Iridomyrmex (Hymenoptera: Formicidae). Zootaxa 2845: 1-174.

Iridomyrmex gibbus n. sp. described from Barrow Island and mainland Australia; I. minor Forel, 1915 recorded from Barrow Island.
Kohout, R.J. (2013). Revision of Polyrhachis (Hagiomyrma) Wheeler, 1911 (Insecta: Hymenoptera: Formicidae: Formicinae). Memoirs of the Queensland MuseumNature 56: 487-577.

Polyrhachis seducta n. sp. described from Barrow Island. 